\title{
Permanent budget surpluses as a
}

fiscal regime

Lukas Haffert: Permanent Budget Surpluses as a Fiscal Regime. In: Socio-Economic Review 17(4), 1043-1063 (2019). Oxford University Press
The original publication is available at the publisher's web site: $h$ ttps://doi.org/10.1093/ser/mwx.050

Lukas Haffert (1) *

Department of Political Science, University of Zurich, Zurich, Switzerland The MPIfG Journal Articles series features articles by MPIfG researchers and vistin
Max Planck Institute for the Study of Societies (MPIfG) Cologne | www.mpifg.de

*Correspondence: lukas.haffert@uzh.ch

\begin{abstract}
This article challenges the focus on budget deficits that permeates the literature on the comparative political economy of fiscal policy. It analyzes countries running budget surpluses and asks why some preserved these surpluses while others did not. Whereas several OECD members recorded surpluses for just a few years, balanced budgets became the norm in Australia, Canada, Denmark, Finland, New Zealand and Sweden in the late 1990s. The article compares both types of countries. Focusing on Canada and Sweden, it argues that a path-dependent shift in the balance of power among competing fiscal policy coalitions explains why surpluses persisted in one group of countries but not in the other. This reconfiguration of fiscal conflict was triggered by a deep fiscal crisis and an ensuing expenditure-led consolidation. It can be interpreted as creating a 'surplus regime,' in which fiscal policy became structured around the goals of balancing the budget and cutting taxes.
\end{abstract}

Key words: public finance, political economy

JEL classification: $\mathrm{H} 6$ national budget, deficit, and debt, P16 political economy, E62 fiscal policy

\section{Introduction: budget surpluses in advanced economies} It is, of course, widely recognized that surpluses are unlikely to arise from deliberate policy action
in a democratic political setting.

James Buchanan (1967, p. 8)

The science of budget balances is a science of budget deficits. At least since the 1970s, scholars of public finance have focused their energies on analyzing a 'deficit bias' of representative democracies (Buchanan and Wagner, 1977; Alesina and Tabellini, 1990; Hallerberg et al., 2009). The opposite case-that of budget surpluses-received a short burst of attention in the late 1990s when the Clinton administration briefly balanced the US 
budget (e.g. Alesina, 2000; Posner and Gordon, 2001), but interest faded quickly when the USA returned to deficit in 2001. Apart from this short-lived exception, the literature has followed Buchanan's lead and regarded surpluses as empirically unlikely to happen and-in case they happened nevertheless—as being of minor theoretical interest (Alesina, 2000; but see Brenton, 2016; Brenton and Pierre, 2017).

This article challenges the widespread neglect of budget surpluses. As Table 1 shows, this challenge can be justified empirically, as surpluses are much more prevalent than is widely assumed. In the three decades between 1980 and 2009-generally regarded as an 'age of permanent austerity' (Pierson, 2001), in which fiscal policy should prima facie have been particularly likely to display 'deficit bias'-13 of 19 traditional OECD economies recorded at least two years of consecutive surpluses (five of them twice), accumulating a total of 115 surplus years between them. Only six advanced economies (Austria, Belgium, France, Germany, Italy, and Portugal) had no surplus period over the entire three decades. ${ }^{1}$

Moreover, surpluses constitute theoretically interesting 'negative cases' (Emigh, 1997) which contradict dominant theories of fiscal policy. While one or two years of surplus do not yet pose a puzzle for the standard view, 10 or 12 years certainly do. Accordingly, this article focuses on countries that ran surpluses for more than a decade and asks how they managed to preserve these surpluses. In other words, whereas the majority of the literature focuses on Step 1 in Figure 1 (e.g. Wagschal and Wenzelburger, 2008; Alesina and Ardagna, 2012; Blyth, 2013; Wenzelburger, 2013; Hübscher, 2016; Hübscher and Sattler, 2017), the focus here is on Step 2. In terms of research design, this implies that the relevant cases are not all OECD economies but only those that achieved a surplus in the first place. The question is why some of them preserved surpluses while others did not. For countries in permanent deficit, this question was never relevant.

This question is different from the question how surpluses are created. Whereas surplus creation is a question of policy change-how to change fiscal policy to overcome a deficitsurplus preservation is a question of policy persistence, i.e. of non-change: how to prevent fiscal policy from changing again. This focus on persistence is important because many observers believe that consolidation successes are persistently threatened by 'consolidation fatigue' (Posner and Gordon, 2001, p. 3; Von Hagen et al., 2002, p. 517). Moreover, it is motivated by an empirical pattern. Table 1 defines a 'surplus period' as a period of at least two years of continuing surpluses, interrupted by at most two deficits before the budget returns to surplus. ${ }^{2}$ The 16 resulting surplus periods fall into two distinct groups. Six of them, which I will refer to as 'surplus regimes', lasted for more than a decade. These surplus regimes developed largely in parallel in the mid-1990s and persisted until the crisis of 2008. In contrast, in 10 cases, which I will call 'surplus episodes', surpluses lasted for a maximum of five years. These surplus episodes are spread over the entire period of investigation.

1 The analysis in this article is restricted to the three decades before the great financial crisis. This crisis fundamentally altered the circumstances of fiscal policymaking (e.g. in terms of interest rates), which limits the comparability of pre-crisis and post-crisis fiscal policy.

2 I allow for such brief interruptions because budget balances only become clear ex post. Therefore, planned surpluses sometimes become deficits due to unexpected events. Moreover, statistical conventions change. For example, after reclassifying the pension system, the OECD now reports deficits for Sweden in 2002 and 2003, even though surpluses were reported at the time. 
Table 1. Budget surpluses in OECD countries, 1980-2009

\begin{tabular}{llllll}
\hline Country & $\begin{array}{l}\text { Surplus } \\
\text { period }\end{array}$ & $\begin{array}{l}\text { Length of } \\
\text { period }\end{array}$ & Structural & $\begin{array}{l}\text { Central } \\
\text { gov. }\end{array}$ & $\begin{array}{l}\text { Decline of net } \\
\text { debt, \% of GDP }\end{array}$ \\
\hline New Zealand & $1994-2008$ & 15 years & $1993-2008$ & $1994-2009$ & $-55.5 \%$ \\
Canada & $1997-2007$ & 11 years & $1997-2000,2004-2007$ & $1997-2007$ & $-46.2 \%$ \\
Finland & $1998-2008$ & 11 years & $1998-2008$ & $1997-2008$ & $-44.9 \%$ \\
Sweden & $1998-2008$ & 11 years & $1997-2009$ & $1998-2008$ & $-39.5 \%$ \\
Australia & $1998-2007$ & 10 years & $1997-2007$ & $1999-2008$ & $-28.5 \%$ \\
Denmark & $1999-2008$ & 10 years & $1999-2000,2004-2008$ & $1998-2008$ & $-41.3 \%$ \\
Japan & $1988-1992$ & 5 years & $1985-1991$ & No data & $-13.3 \%$ \\
Denmark & $1986-1989$ & 4 years & $1986-1990$ & $1986-1989$ & $-8.3 \%$ \\
Iceland & $2004-2007$ & 4 years & $2005-2007$ & $2004-2007$ & $-31.7 \%$ \\
Sweden & $1987-1990$ & 4 years & $1986-1990$ & $1987-1990$ & $-20.6 \%$ \\
Netherlands & $2006-2008$ & 3 years & $2005-2006$ & $2005-2008$ & $-8.0 \%$ \\
Spain & $2005-2007$ & 3 years & $2005-2007$ & $2005-2007$ & $-16.9 \%$ \\
UK & $1999-2001$ & 3 years & $1999-2001$ & $1998-2001$ & $-9.2 \%$ \\
USA & $1998-2000$ & 3 years & 2000 & $1998-2001$ & $-13.5 \%$ \\
Iceland & $1999-2000$ & 2 years & $1999-2000$ & $1997-2000$ & $-5.1 \%$ \\
Netherlands & $1999-2000$ & 2 years & 2000 & $1999-2000$ & $-13.3 \%$ \\
Finland & $1980^{\mathrm{b}}-1989$ & 10 years & $1980^{\mathrm{b}}-1990$ & $1986-1990$ & \\
Switzerland & $2006-2009^{\mathrm{b}}$ & 4 years & $2006-2009^{\mathrm{b}}$ & $2006-2009 \mathrm{~b}$ & \\
Overlap & & & $79.3 \%$ & $80.5 \%$ & \\
\hline & & & & &
\end{tabular}

Note: This table excludes Ireland, Luxembourg and Norway, which all recorded persistent budget surpluses. However, Ireland's surplus was an artifact of an overheating economy (the structural balance was negative for most of the 2000s), while Luxembourg and Norway benefit from unique geographical/geological circumstances. Furthermore, I exclude Finland in the 1980s and Switzerland from the analysis. Finland had already been running persistent surpluses since the 1950s to finance a state-driven industrialization effort (Vartiainen, 2011, p. 60). This approach changed fundamentally after 1990. The Swiss surplus started in 2006 but did not end in 2009, making the data right-censored.

Source: OECD Economic Outlook No. 92 Database.

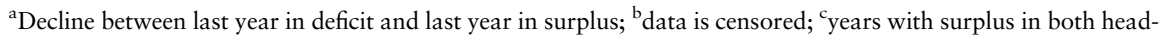
line and structural/central government balance, divided by years with surplus in at least one of them.

As Table 1 shows, the groups of surpluses are quite distinct, no matter whether one looks at the general government, the central government or the structural balance. Surplus regimes lasted for an average of 11.3 years and were thus clearly a structural phenomenon. They also led to a massive and lasting reduction of net indebtedness. Surplus episodes, by contrast, lasted for only 3.3 years on average and are best understood as a cyclical phenomenon. In fact, they closely correspond to peaks in the global business cycle. Their effect on net indebtedness was much smaller and largely transitory. Thus, the two groups indeed represent the path divergence depicted in Step 2 of Figure 1.

The article aims to explain this divergence between the two groups of cases. Why did balanced budgets develop into surplus regimes in some cases but not in others? In asking this question, the emphasis is on those countries that preserved surpluses. Whereas surplus episodes conform to the received wisdom, surplus regimes constitute a puzzle for any theory positing a general deficit bias. The empirical analysis will therefore concentrate on explaining their distinctiveness. 


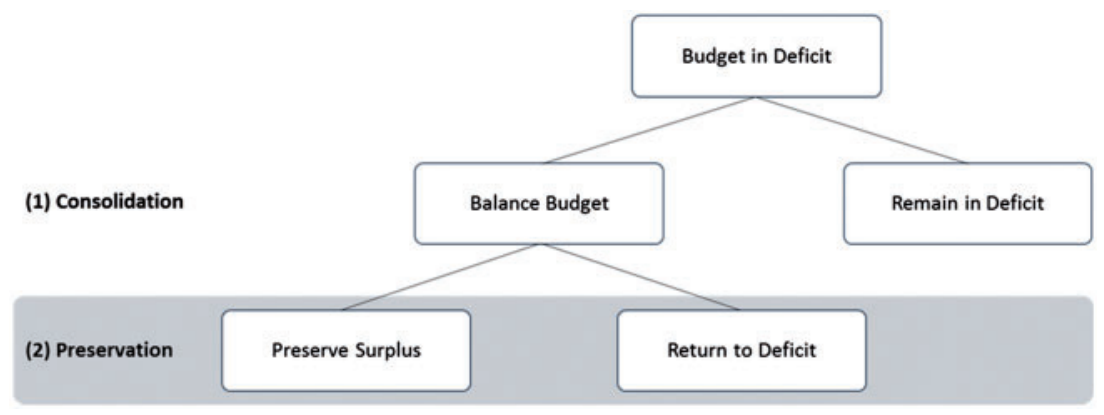

Figure 1. Surplus generation and surplus preservation.

In doing so, my argument will focus on the relative power of coalitions supporting different fiscal policies. Specifically, I argue that countries preserved surpluses when a fiscal crisis and a subsequent expenditure-led consolidation triggered a persistent shift in the balance of fiscal interests and empowered a coalition favoring a new fiscal regime. In contrast, surpluses remained an episode when countries did not experience a similar fiscal crisis and based their consolidation on revenue increases. Surpluses were therefore not accompanied by a fundamental reconfiguration of fiscal interests and fiscal policy, notwithstanding brief surpluses, remained stuck in a 'deficit regime'.

The following section develops this theoretical framework and explains how I conceptualize the persistence of surpluses. Focusing on the experiences of Canada and Sweden, the empirical core of the article then traces the differences between the two groups of countries through a process of fiscal crisis, consolidation and surplus spending. The final section concludes and discusses why it is justified to talk of a new 'regime' in countries where surpluses were preserved.

\section{Theory: coalitions, fiscal regimes and the persistence of surpluses}

Because surpluses have received little attention in the literature, there are to date no direct attempts to explain the differences between surplus regimes and surplus episodes. However, the dominant approaches in the literature, while able to conceptualize surplus episodes, are clearly insufficient to explain surplus preservation.

This is true of functionalist explanations, which would argue that countries with surplus regimes are simply small open economies that find it easier to run tight fiscal policies (Buti and Pench, 2004). Yet, while in some bigger economies-USA, Japan, the UK-surpluses indeed remained an episode, the same is true of several small economies, suggesting that the size of the economy is at most one among several explanatory factors and cannot replace a political account. Similarly, institutionalist accounts which would argue that PR systems can easier commit to specific policies (Cox and McCubbins, 2001), including budget surpluses, cannot explain why Canada and Australia preserved surpluses, whereas the Netherlands did not.

Most importantly, surplus preservation constitutes a puzzle for explanations of a deficit bias of representative democracies that derive from the public choice tradition. In these 
models, policymakers try to maximize their self-interest, given a certain incentive structure. The prediction of a deficit bias follows straightforwardly: because tax cuts and spending are popular, whereas tax increases and retrenchment are unpopular, balancing the budget is not in the self-interest of vote-seeking politicians. Instead, fiscal policy is plagued by a common pool problem, time inconsistency, fiscal illusion, strategic use of debt, issues of intergenerational redistribution, electoral cycles and other conceptually similar problems (for a summary see Alesina and Passalacqua, 2015).

In this framework, deficits arise because policymakers have too much discretion. The suggested solution, therefore, is to restrict their room for maneuver-or, in Aaron Wildavsky's terms, to strengthen the guardians against the spenders (Wildavsky, 1975). Accordingly, economists and political scientists have proposed a host of formal institutional reforms, such as balanced budget rules (Buchanan and Wagner, 1977), expenditure rules (Ljungman, 2008), fiscal councils (Calmfors and Wren-Lewis, 2011), centralized budgetary processes (Hallerberg, 2004), or binding coalition agreements (Hallerberg et al., 2009). Following this literature, institutional reforms should be key for the preservation of surpluses. However, this explanation begs the question why countries reform their institutional framework in the first place. Often, such reforms will be introduced by countries already committed to fiscal thriftiness and thus rather be an effect than a cause of fiscal policy change.

This study proposes to analyze the persistence of surpluses on a much broader canvas and to endogenize specific policy decisions like the introduction of fiscal rules. Following war of attrition models of fiscal consolidation (Alesina and Drazen, 1991; Barta, 2011), I conceptualize fiscal policy as a conflict between two policy coalitions, one calling for higher expenditure and one calling for lower taxes. However, whereas these models are usually employed to explain the timing of consolidation, I apply them to consolidation's persistence.

Expenditure and tax-cut coalitions fight over the size and composition of the public budget. In this struggle they draw on various sources of political strength, including institutional frameworks, ideational resources and electoral support. Heuristically, the expenditure coalition contains the beneficiaries of public redistribution and public services, but also their producers (i.e. public servants). Core coalition members are labor unions, in particular in domestically oriented sectors of the economy which benefit from an activist, anti-cyclical fiscal policy and are comparatively sheltered from global tax competition. Ideationally, the coalition coalesces around the vision of an activist state and conceptualizes fiscal policy as an important discretionary instrument for managing the economy. It benefits from an institutional framework that gives political decision makers wide room for maneuver. The partisan literature typically considers parties of the left as the political representatives of this coalition (Franzese, 2002).

The tax-cut coalition, by contrast, brings together net contributors to public redistribution, but also employees in export-oriented sectors for whom deficit spending holds little promise but who see their fortunes threatened by international tax competition. Naturally, business associations are core coalition members. Ideationally, this coalition coalesces around the vision of a lean state and conceptualizes fiscal interventions as harmful to economic efficiency. It draws support from an institutional framework that guarantees a rulebound fiscal policy and restricts political discretion. Typically, parties of the right are the representatives of lower taxes. 
Obviously, the political efficacy of the two coalitions will systematically differ between different countries. Expenditure coalitions can draw on much bigger institutional resources in universal welfare states than in residual welfare states, for example. In fact, one could interpret the size and structure of the welfare state as the outcome of the long-term balance of power between the two groups. ${ }^{3}$

Moreover, following Iversen and Soskice (2006), not all voters or interest groups will be closely attached to one of the two coalitions. These pivotal actors can potentially ally with both coalitions and are thus the target of political competition. Structurally, members of this group should be closer to the expenditure coalition in universalistic welfare states, where they consume many public services. In more residual welfare states, they have to buy these services on the market and are therefore more supportive of tax cuts, which increase their disposable income. ${ }^{4}$

The balance of power between these coalitions shifts over time with changes in the ideational context, the institutional framework or the structure of material interests. More importantly for the purposes of this article, there are also phases in which the balance of power reaches a relatively stable equilibrium. Following Paul Pierson (Pierson, 2001; see also Streeck, 2017), we may describe such an equilibrium as a 'fiscal regime'. Pierson defined such a regime as 'the configuration of political interests, institutions, and policy arrangements that structure conflicts over taxes and spending' (Pierson, 2001, pp. 56-57).

This regime takes the form of a 'deficit regime' when neither coalition is strong enough to impose its will on the other coalition, as both coalitions, though in principle committed to balanced budgets, refuse to carry the burden of balancing the budget. In this case, the expenditure coalition successfully resists expenditure cuts, the tax-cut coalition vetoes tax increases and the undecided middle benefits from a low level of taxation and a high level of public services. Such a deficit regime characterized many Western economies after 1973, when expenditure coalitions lost their post-war dominance but tax-cut coalitions were not able to establish a new structural supremacy. However, the situation is very different in regimes in which one coalition clearly dominates. These regimes allow for a structurally balanced budget because one coalition is able to impose the costs of balancing the budget on the other side. This dominant coalition is thus able to achieve its most important goal without having to sacrifice budget balance. For example, before 1973 expenditure coalitions dominated Western political economies and budgets were generally balanced.

Applying this perspective to the question of surplus persistence after 1980, my core argument is that fiscal policy remained embedded in the existing deficit regime in countries with surplus episodes, while fiscal regime change occurred in countries which preserved surpluses. The balance of power between both coalitions remained unchanged in the former group but shifted toward a dominance of tax-cut coalitions in the latter.

This argument raises the question how to explain regime change in some surplus countries. Here, the extensive literature on critical junctures (Capoccia and Kelemen, 2007)

3 Here, my approach has obvious affinities to power-resource theory (Esping-Andersen, 1990).

4 Obviously, fiscal policy conflicts in the real world are more complicated than in this stylized model. Interest groups typically support specific expenditure programs (specific tax cuts), rather than a bigger (smaller) budget as such. Still-like a single left-right axis is a helpful simplification of multidimensional partisan conflict about economic policy-the stylized unidimensional conflict has heuristic value. 
suggests an important role for fiscal crises. A crisis fundamentally questions the established regime and can thus create the 'permissive conditions' (Soifer, 2012) for regime-changing reforms. This is particularly likely when the crisis involves the intervention of international markets or international organizations who may be able to break a stalemate between the coalitions. Whether a crisis indeed forms a critical juncture will thus have to do with the specific circumstances of the crisis itself. However, it also depends on the reaction to the crisis. Fiscal crises will trigger consolidation everywhere, but not every consolidation is equivalent to fiscal regime change. Most consolidations are just adjustments within an existing regime. Only a consolidation that transforms 'political interests, institutions, and policy arrangements' will have long-term consequences on the regime.

The proposition that the design of a consolidation program affects its sustainability is a staple of the consolidation literature (e.g. Alesina and Perotti, 1995; Alesina and Ardagna, 2012). According to their results, consolidations relying on expenditure cuts (in particular welfare and, more specifically, pension cuts, Wenzelburger, 2013) are much more likely to persist than revenue-based consolidations. However, when these studies investigate the sustainability of consolidation efforts, they restrict themselves to a two-year (Alesina and Ardagna, 2012) or three-year window (Wagschal and Wenzelburger, 2008) for defining sustainability. Similarly, studies using duration analysis usually only look at the period during which the structural balance improves (Mulas-Granados, 2006). In contrast, this study analyzes persistence on a much longer scale. ${ }^{5}$ Moreover, the economic literature does not offer a political explanation for this empirical finding. Typically, it argues that expenditure-based consolidation induces greater confidence and is therefore less harmful to economic growth. However, this does not explain why policymakers refrain from using the additional leeway to reverse cuts. In other words, which political mechanism makes expenditure-led consolidation more politically sustainable than revenue-driven consolidation?

My answer is that different types of consolidation affect the balance of power between fiscal coalitions very differently. In an important study of the reversal of policy reforms, Eric Patashnik (2008) argues that a core quality of sustainable reforms is the destruction of old coalitions. A reform is likely to persist only if reform opponents are prevented from mounting a powerful counterattack.

This is exactly what happens during expenditure-driven consolidation. It weakens spending coalitions by making the welfare state more residual, but leaves tax-cut coalitions largely unaffected. Those who have always demanded lower taxes keep doing so while those whose public services have been cut are induced to develop private alternatives and to rely less on-and ask less from—the state (Campbell, 2012 reviews potential mechanisms behind such an effect; for empirical support see Busemeyer and Iversen, 2014). Ideationally, expenditure-driven consolidation requires an attack on the image of an activist state that uses fiscal policy to shape economy and society. Moreover, when consolidation is accompanied by institutional reforms, these reforms usually try to limit public spending and undermine the institutional support for expenditure coalitions.

Revenue-driven consolidation, by contrast, does not have similar negative feedback effects. It leaves spending coalitions largely unaffected but strengthens tax-cut coalitions. Those who pay higher taxes may join the ranks of the tax-cut coalition, while no one is

5 Thus, whereas Alesina\&Ardagna code both Canada and the UK as 'sustainable consolidations' in the 1990s, I code the latter as surplus episode. 
induced to leave the spending coalition. Similarly, revenue-driven consolidation does not affect the ideational background of either coalition: For supporters of expenditure, it reaffirms the image of an activist state, whereas in the eyes of tax-cut supporters, it emphasizes the need for a lean state even more. Finally, institutional reforms almost never attempt to increase public revenue structurally and to strengthen spending coalitions.

The political effects of revenue- and expenditure-led consolidation are therefore very different. Expenditure-led consolidation is much more likely to induce fiscal regime change than revenue-led consolidation. By shifting the balance of power to a new stable equilibrium, it can give rise to a new surplus regime, whereas other countries remain stuck in a deficit regime, even if they run surpluses for a few years.

\section{Empirics: from deficit crisis to surplus regime}

Based on these theoretical considerations, the empirical analysis needs to show three things: the differences of fiscal trajectories between the two groups of cases (regimes and episodes), the commonalities within the two groups and the specific coalitional dynamics behind these trajectories. In order to balance these somewhat competing goals, I focus on surplus regimes, as they form the theoretically interesting 'negative cases' (Emigh, 1997). I thus aim to demonstrate how fiscal outcomes and coalitional balances developed broadly similar in surplus regimes but differed systematically from the development in surplus episodes, using surplus episodes as a background comparison.

Because six cases are too few for elaborate statistical tests but too many for a comprehensive treatment of all of them, I combine descriptive overviews of all six surplus regimes with an in-depth treatment of two cases. The aim is to uncover the underlying commonalities within surplus regimes. Therefore, I analyze two diverse cases, Sweden and Canada, which represent the institutional heterogeneity of this group of three social democratic and three liberal welfare states. Together with the descriptive overviews, this selection of institutionally diverse cases should allow me to generalize my findings to all six surplus regimes.

My theoretical argument implies that different surplus countries were already on different paths when they first balanced their budgets. The analysis thus focuses on the fiscal conditions in the years preceding the surpluses and on the ensuing consolidation efforts. Specifically, I investigate how these events affected the strength and cohesion of spending and tax-cut coalitions, and thus reconfigured their balance of power in the medium and long term.

\subsection{Surplus regimes experience financial market pressure}

All six countries that would later develop surplus regimes experienced unique fiscal and macroeconomic difficulties in the late 1980s and early 1990s (Schwartz, 1994). One symptom of these crises was high budget deficits and rising debt-to-GDP-ratios. Yet, deficits also grew in many other countries, and headline numbers were even worse in Belgium, Italy or Japan. What distinguished these countries was not the absolute size of their problems but the rapid deterioration of their situation. They all started from a strong fiscal position and lost the trust of financial markets during the crisis.

Two indicators of financial market pressure demonstrate this: credit ratings and interest rates on government bonds (Table 2). All six countries were downgraded during this period, and some of them several times. In contrast, no other OECD members (including surplus 
Table 2. Rating downgrades and interest rate spreads in OECD countries, 1980-2000

\begin{tabular}{lll}
\hline Country & Downgrade by Standard \& Poor's & $2 \sigma$ hike of interest rate spreads \\
\hline Australia & $02.12 .1986:$ AAA to AA + & $1986-1987$ \\
& $24.10 .1989:$ AA + to AA $(\mathrm{neg})$ & 1989 \\
Canada & $14.10 .1992:$ AAA to AA + & 1990 \\
Denmark & $06.01 .1983:$ AAA to AA + & 1982 \\
& $07.03 .1985:$ AA+ to AA & \\
Finland & $03.03 .1992:$ AAA to AA + & 1990 \\
& $11.03 .1993:$ AA + to AA - & 1992 \\
New Zealand & $29.04 .1983:$ AAA to AA + & 1985 \\
& $02.11 .1986:$ AA + to AA & 1986 \\
& $22.01 .1991:$ AA to AA - & 1987 \\
Sweden & $22.03 .1993:$ AAA to AA + & 1990 \\
Other OECD members & $/$ & $/$ \\
\hline
\end{tabular}

Source: Baldacci et al. (2011); Standard \& Poor's (2011).

episode countries) were downgraded between 1980 and 2000 (Japan was downgraded in 2001). Moreover, the spread between the interest rate on their debt and the interest rate on US treasuries temporarily rose by more than two standard deviations above its long-term average in all six countries. Again, no other OECD economy experienced such a spike in this period (Baldacci et al., 2011). While some surplus episodes also followed on fiscal troubles-in particular, in the Netherlands-financial market pressure did not become as acute in any of them. Rating downgrades and interest rates thus provide an important first distinction between the two groups of cases.

Fiscal crises themselves, however, not yet explain why crisis countries later developed surplus regimes. This, instead, depended on the disruption of the existing balance of fiscal coalitions, as can be seen in both Canada and Sweden. In both cases, the crisis fundamentally weakened expenditure coalitions by questioning the countries' social and economic models.

Sweden was hit by a deep financial and economic crisis in the early 1990s (Lindbeck, 1997). The deficit peaked at $11.2 \%$, the employment ratio fell from $83 \%$ to $71 \%$ (Timonen, 2003 , p. 87), and the Krona had to be devalued, despite the Swedish central bank's fervent attempts to defend the exchange rate (Mehrtens, 2014). Commentators even speculated about an imminent IMF-intervention (Henriksson, 2007, p. 5).

In reaction to this crisis, policymakers started to question existing fiscal arrangements and voters became willing to support harsh expenditure cuts. As Sven Steinmo observes: 'Whereas in the past [Swedish] elites believed they could manage their economy quite effectively, now they were increasingly convinced that such management was no longer possible' (Steinmo, 2002, p. 848). This feeling was most prominently embodied by finance minister Göran Persson, who motivated his insistence on structural consolidation with his experience of having to face a 'sneering young financial mob on Wall Street' (quoted in Nuder, 2012, p. 59). Voters also shared this crisis sentiment. Among the public, according to Persson ' [...] there was an awareness [...] that we really had a problem. There was a crisis-awareness' (quoted in Wenzelburger, 2010, p. 184; see also Calmfors, 2012, p. 18). Indeed, in the 1994 
election voters gave the Social Democrats a clear mandate for wide-ranging austerity policies.

Political developments in Canada were very similar, although the crisis was more chronic than in Sweden. After years of rising debt-to-GDP ratios, the federal government had to pay almost 36 cents of every tax-Dollar for servicing the debt (Lewis, 1999, p. 151). Symbolic events like the Wall Street Journal's description of Canada as an 'honorary member of the Third World' (Courchene, 2002, p. 23) or the near-failure of a bond auction (Palmer and Egan, 2011) left a deep impression on elites and voters alike (Fortin, 1996). In 1993, concern for the deficit surpassed unemployment as the most important policy issue (Bourgon, 2009, p. 12). As Timothy Lewis summarizes the politically dominant diagnosis of the Canadian crisis:

[E]xperiencing deep economic insecurity, people felt their economic situations to be precarious; people conceptualized the state, and particularly its welfare functions, as the problem; and people supported parties that promised to restore control over their economic lives by eliminating the deficit and retrenching the state (Lewis, 2003, p. 145).

In other words, the existing balance between fiscal coalitions had started to shift. This was demonstrated by so-called 'earthquake elections' (Lewis, 2003; Arter, 2012, p. 827). In the Swedish election of 1991, several fringe parties, which before the mid-1980s had been irrelevant in Sweden's traditional five-party system, obtained $18 \%$ of the votes, whereas the Social Democrats fell below 40\% for the first time since 1928 (Arter, 2012, p. 835). In Canada, in the election of 1993, the governing Progressive Conservatives collapsed from $43 \%$ to $16 \%$ of the vote and lost 154 of their 156 seats. Moreover, the Quebec referendum in 1995 questioned the continued existence of the Canadian federation. While this referendum was mainly about constitutional issues, fiscal policy played a role insofar as a cashstrapped federal government was increasingly unable to financially pacify Quebecois separatism (Weaver, 1992).

The crises thus constituted a double-challenge for expenditure coalitions. First, they undermined the coalitions' ideational basis by fundamentally questioning their vision of activist government. Secondly, they weakened the coalitions' electoral support by raising voters' willingness to accept fundamental reforms that cut back the reach of the state. Parties of the center-left thus faced a choice to either accommodate these preference shifts or to risk electoral defeat. Together, these developments created the conditions for a durable reconfiguration of the balance of power between expenditure and tax-cut coalitions.

\subsection{Consolidation in surplus regimes is expenditure driven}

In reaction to their fiscal crises, countries that preserved surpluses engaged in massive consolidation programs to reduce deficits and win back the trust of financial markets. Yet, countries where surpluses remained episodes also undertook sometimes quite sizeable consolidation efforts. However, their composition differed considerably between the two groups.

As Figure 2 shows, budget consolidation in surplus regimes focused almost entirely on the expenditure side of the budget, no matter how one defines the consolidation period. In contrast, countries with surplus episodes relied much more on increasing revenue. This finding from cyclically adjusted data is confirmed by the narrative method of DeVries et al. 


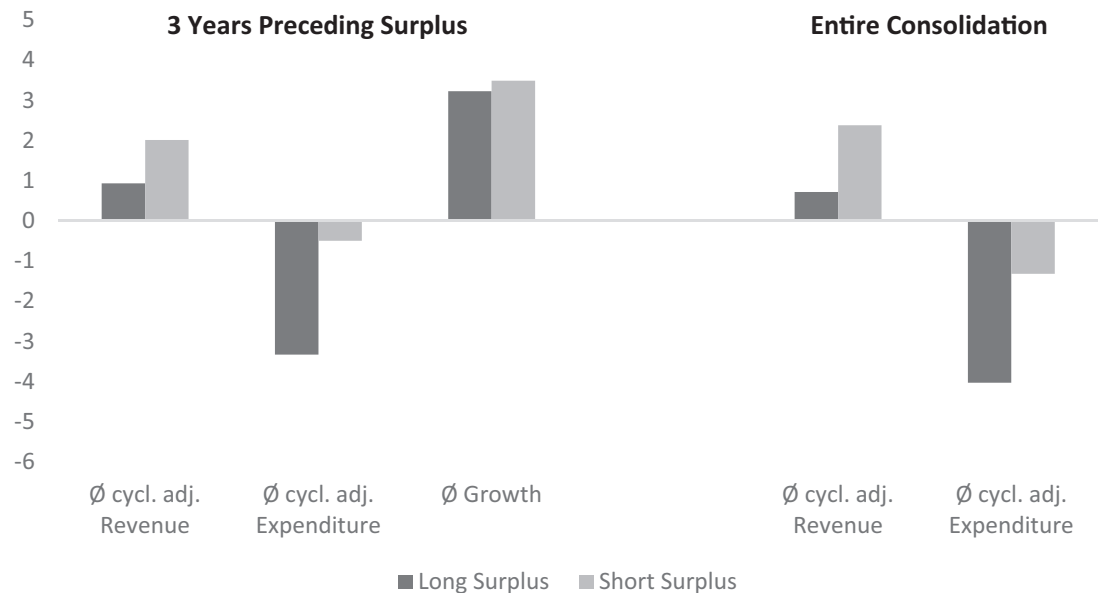

Figure 2. Composition of consolidation preceding budget surplus.

Source: OECD Economic Outlook No. 92 Database.

(2011) for Australia, Canada, Finland and Sweden. New Zealand is not part of their dataset, and the Danish case is somewhat ambiguous. According to their data, almost all consolidation efforts in Denmark happened in the 1980s. ${ }^{6}$ Thus, different measures of consolidation find an expenditure focus in surplus regimes.

This expenditure focus was particularly pronounced in Canada. Nominal program spending (i.e. all non-interest spending) by the federal government fell from 120 billion dollar in fiscal year 1993/1994 to 108.8 billion in $1997 / 1998$, a decline by almost $25 \%$ in real dollars (Department of Finance Canada, 1999). As a share of GDP, program spending fell to its lowest level since 1950 (Bourgon, 2009, p. 19). In Sweden, the government argued that two-thirds of announced consolidation measures were spending cuts (Persson, 1996), although actual budgetary developments suggest an even higher contribution of spending measures.

Expenditure-driven consolidation weakened spending coalitions on two levels: first, concerning the supply of public services, the state considerably reduced the number of public servants. In the course of the consolidation, the Canadian federal government cut 45000 jobs, equivalent to $14 \%$ of its workforce (Sancak et al., 2011, p. 38). Sweden reduced the

6 Denmark slightly deviates from the sequence of crisis and consolidation presented here. The Danish crisis culminated already in the early 1980s. Denmark then ran budget surpluses from 1986 to 1989, thereby inspiring the literature on expansionary austerity (Giavazzi and Pagano, 1990). However, these surpluses were caused by an economic boom that was driven by low interest rates and rising house prices, but not accompanied by an expansion of the economy's productive capacity (Nannestad and Green-Pedersen, 2008). When the government introduced contractionary measures, the boom collapsed and Denmark entered a phase of stagnation from 1987 to 1993, during which the deficit again ballooned to almost $4 \%$ of GDP. Thus, the surplus of the 1980s is rather an element of an unfolding crisis sequence than an expression of fiscal policy success. Only the consolidation efforts of the 1990s, constructed around a set of 'activating' labor market reforms (Gaard and Kieler, 2005), managed to turn Danish public finances around permanently. 
number of public service employees from 1.4 million to less than 1.1 million between 1990 and 1998 (Mehrtens, 2014, p. 150). These cuts were much more pronounced than the parallel developments in surplus episodes (ILO, 2013). Moreover, the public sector did not just shrink; both countries reorganized it along the principles of New Public Management (Brenton, 2016). These reforms clearly reduced the scope of public activity. Moreover, they also alleviated budgetary pressures, as 'reorganization was intended to reduce the bargaining power and thus the wages of workers in the public sector' (Schwartz, 1994, p. 546). In terms of coalitional balance, the shrinking size and the reorganization of the public sector weakened public sector unions, a traditional stronghold of expenditure coalitions.

In Canada, public sector reforms were embedded in a so-called 'Program Review', in which the government aimed to evaluate whether expenditure programs were still in the public interest and required the involvement of the federal government (Wenzelburger, 2010, p. 240). Moreover, it also reorganized inter-governmental fiscal relationships, thereby isolating Ottawa from spending pressures arising in the provinces (Kelly, 2002, p. 76). The structural weakening of expenditure coalitions was thereby also extended to lower levels of government.

Secondly, demand for public services also declined in response to the privatization of these services. This is particularly visible in Sweden, which had always been the epitome of the social democratic service state (Huber and Stephens, 2000). In fields like elderly care, education, health and childcare, a substantial share of services is today delivered by private providers although it is still financed by the state (Gingrich, 2011; Mehrtens, 2014). In a process of layering, these private structures have increasingly replaced classical stateprovided public services. This 'choice revolution' (Blomqvist, 2004) allowed important constituencies to 'exit' the public system and leave it and its problems behind (Schwartz, 1994, p. 530), instead of having to use 'voice' to demand a political reaction to their discontent. Supporters of a strong service state were weakened as public services acquired a more residual character and no longer included all social groups. Accordingly, increasing polarization about the goals for public education, as documented by Fladmoe (2012), leads to more exit into private schools instead of a strengthening of the public system.

Crisis and consolidation thus triggered a kind of self-fulfilling prophecy: they led citizens to expect cuts to public programs and thus to rely less on the state. In a 1997 survey, the large majority of Swedes expected that the public pension would not guarantee an acceptable standard of living and would have to be complemented with private insurance (Edlund, 2006, p. 399). Moreover, those who saw particularly strong needs for private insurance were more likely to hold 'abandon the welfare state' sentiments (Edlund, 2006, p. 407). The fact that citizens increasingly invested in alternatives to state provision, in turn, made the expected cuts politically viable (for Canada, the same point is made by Lewis, 2003, p. 162). Ex post, cuts then seemed to confirm how prescient it was not to rely on the state.

That citizens increasingly relied on private alternatives, however, did not mean that public programs became less popular in general. Today, the Swedish welfare state is even more popular than before the crisis (Svallfors, 2011). However, this popularity has not been translated into expansionary policies. This again demonstrates how important it is to differentiate between policy change and policy preservation. While this popularity ensures that the expenditure coalition can successfully resist further retrenchment, protection from retrenchment and renewed expansion are entirely different issues. Popularity alone did not restore the expenditure coalitions' organizational capacities and political clout that had been lost 
during the consolidation but would have been necessary for pushing policy change (Haffert and Mehrtens, 2015; Svallfors, 2016).

Another important facet of the decline of expenditure coalitions was that all major parties supported the consolidation measures. In Sweden, the bourgeois government and the oppositional Social Democrats already agreed on several savings measures in 1992. From 1994 onwards, the new Social Democratic minority government then relied on the support of the Left Party in some cases and on the agrarian Centre Party in others. As Virpi Timonen argues, all parties 'that participated in [...] Swedish governments between 1991 and 1998 considered low inflation and reduction of the budget deficit the most important goals of economic policy' (Timonen, 2003, p. 45). In Canada, the Liberal governments' expendituredriven consolidation was emulated by provincial governments of all stripes in Ontario (Progressive Conservatives), Alberta (Reform Party) and Saskatchewan (New Democrats) (MacKinnon, 2003).

Campaigning on the success of their consolidation programs, the Canadian Liberals and the Swedish Social Democrats were reelected in 1997 and 1998, despite their retrenchment policies. While both parties lost votes, the election results were generally seen as a positive verdict on the consolidation measures. In fact, both finance ministers during the consolidation, Paul Martin and Göran Persson, later became prime ministers. Thus, both countries had governments strongly committed to preserving consolidation. Moreover, opposition parties could not credibly attack consolidation governments, as they had been deeply involved in the austerity measures. Instead, they tried to present themselves as offering even greater fiscal responsibility. When the Canadian budget outlook deteriorated in 2001, Reform's shadow minister of finance criticized that ' $[. .$.$] the government is now in a plan-$ ning deficit and is skating oh so close to an actual deficit. It is skating far too close to threatening the progress that Canadian taxpayers have made over the past years in the hard won fight against the deficit' (Kenney, 2001).

Finally, consolidation efforts were associated with a shift in these countries' growth models toward a greater reliance on exports. Institutionally underpinned by Sweden's EU accession and the introduction of NAFTA, exports jumped from $26 \%$ to $40 \%$ of GDP in Sweden and from $24 \%$ to $38 \%$ in Canada between 1991 and 1997. This strengthened the hand of export interests and weakened domestic sectors with an interest in an activist and countercyclical fiscal policy.

Expenditure-driven consolidation thus weakened expenditure coalitions by changing the material basis for their electoral support and by triggering a re-positioning of those parties that had traditionally been their main representative. Moreover, they also undermined these coalitions' ideational basis by apparently demonstrating that the days of a strong and activist fiscal policy were over and that a return was not possible. All three types of actors that could potentially voice a demand for more expenditure (labor unions, left and center-left parties and citizens themselves) thus became either less likely to do so or simply less influential.

\subsection{The role of institutional reforms}

The main challenge to my coalition-based explanation of surplus persistence comes from a public choice account that sees the solution to democracy's posited deficit bias in reforms of fiscal institutions. And indeed, according to an IMF study, countries with surplus regimes 
introduced on average more than three times as many new fiscal rules during or after consolidation as countries with surplus episodes (Budina et al., 2012).

Nevertheless, these numbers should be interpreted carefully. First, several of these countries, including Canada (Blöndal, 2001), had introduced similar reforms before, yet without major success. In contrast, governments generally complied with the rules of the late $1990 \mathrm{~s}$ and early 2000s. It is hard to explain these very different outcomes with inherent differences of the reforms.

Secondly, these reforms had rather weak formal power. In many cases, reforms were not even codified or did not contain enforcement mechanisms for punishing deviations from fiscal targets (which were themselves often rather abstract, Brenton and Pierre, 2017, pp. 9-10). In a public choice framework, it is not clear why politicians should obey such a weak rule.

Thirdly, as the IMF observed for Sweden, governments sometimes pursued even tighter policies than demanded by the rules (IMF, 2002a, p. 4). The Canadian Liberals gave up on their predecessors 'Spending Control Act' because they regarded it as redundant (Brenton, 2016, p. 79). Hence, institutional rules did not really force political choices that would otherwise not have been made.

Finally, the most important change in the budgetary process was not formalized at all: namely, a tendency to base budgets on pessimistic assumptions and to underestimate surpluses. This was no accidental result of positive macroeconomic surprises but politically intended (Persson, 1996). At the same time, it was emphatically not the consequence of any formalized pressure on governments (Kelly, 2002, p. 77). To the contrary, the Canadian parliament challenged the government to provide more accurate forecasts (O’Neill, 2005).

Taken together, these objections suggest that institutional reforms were not the exogenous cause of fiscal policy change, but one of its endogenous elements. They expressed shifts in the coalitional balance of power that had been triggered by fiscal crises. As far as the reforms had independent effects, they undermined the institutional support for the expenditure coalition by formalizing the idea that the cost of balancing the budget should be borne by the expenditure side (see below).

\subsection{Surplus persistence and tax cuts}

As the analysis of crisis and consolidation has made clear, the two groups of countries were already on very different trajectories when they first balanced their budgets. However, these differences did not yet show in headline numbers. This changed when the economic booms, which fed the first years of surpluses, ran out of steam. Confronted with adverse macroeconomic developments, some countries managed to preserve surpluses while others returned to permanent deficits.

The different political reaction to macroeconomic shocks is demonstrated by how the 10 countries having a surplus in 2000 (the six surplus regimes and Iceland, the Netherlands, USA and the UK) dealt with the global economic downturn of 2001-2003. Figure 3 shows a clear difference in their discretionary reaction to the downturn. Countries with surplus regimes were more reluctant to cut taxes and much more reluctant to increase expenditure. Taken together, the fiscal stimulus provided in surplus episodes was more than three times as big as the stimulus provided in surplus regimes. The latter let automatic stabilizers do their work, but were reluctant to use discretionary measures to stabilize their economies. In fact, Sweden in 2003 introduced discretionary cuts in order to protect the surplus (Lindh and Ljungman, 2007, p. 43). 


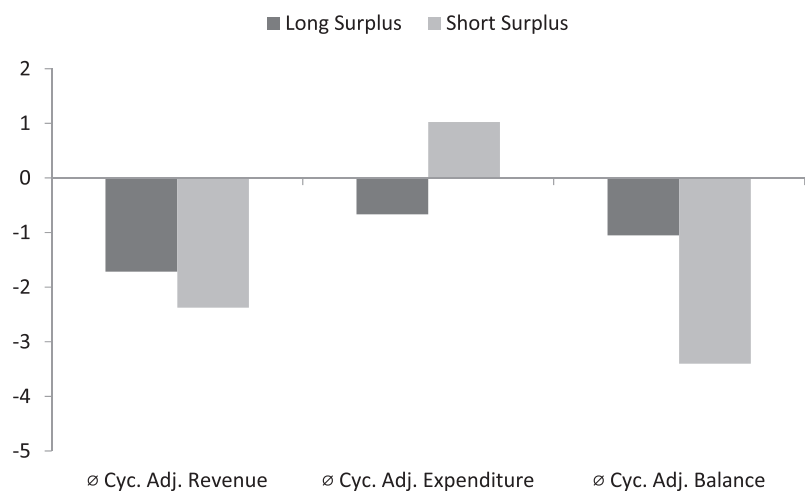

Figure 3. Fiscal reaction to the recession of 2001-2003; short surplus cases are Iceland, the Netherlands, UK and USA.

Source: OECD Economic Outlook No. 92 Database

Canada also abstained from major fiscal expansion. The budget introduced in December 2001, at the height of the post $9 / 11$ uncertainty about the course of the economy, contained expansionary measures of just 4.7 billion dollar (Department of Finance Canada, 2001, p. 21). This tight reaction was not simply an economic necessity, but a political choice. Even the IMF suggested the possibility of a more expansionary stance, yet to no avail: 'The authorities expressed great misgivings about engaging in discretionary stimulus measures, even in the face of a more pronounced downturn' (IMF, 2002b, p. 21). A stimulus was simply not politically expedient, as Finance Minister Paul Martin explained, thereby appealing to voters and to export industries. Voters, he argued, rejected a more expansionary approach, as the crisis experience was still fresh: 'Canadians remember the hard choices of the 1990s as we worked to pull ourselves out of deficit. We will not play fast and loose with the finances of the nation' (Martin, 2001, p. 21). And export sectors, which were increasingly important since Canada had become a much more open economy, did not benefit from fiscal stimulus: 'Our choices also reflect a clear-eyed assessment of what we can and cannot do. Simply put, we cannot turn around the American economy - our largest export market.' (Martin, 2001, p. 19).

The Liberals thus rightly judged that calls for a more expansionary stance did not have the support of the public's, nor of the most important organized interests. A 2002 poll confirmed the public fiscal conservatism: a full $57 \%$ of voters demanded that new spending should be financed by cuts elsewhere, whereas only $27 \%$ accepted lower surpluses or even deficits (Maclean's, 2002). And as we have seen above, Reform, the biggest opposition party, called for even stricter fiscal policies (Kenney, 2001).

The Liberal's tight approach was a big political success, as the downturn was much milder than anticipated. Thus, the government quickly claimed that its prudent fiscal approach had been responsible for the mildness of the recession (Goodale, 2004). In their rhetoric, surpluses turned from being an outcome of economic growth to being a precondition for it. This redefinition obviously could not happen in countries with surplus episodes: claiming that surpluses were an engine of growth would have been a damning verdict on their own expansionary policies. 
After the recession of 2001-2003 had been overcome, a strong macroeconomic environment characterized the years before the world financial crisis in surplus regimes. This further strengthened public finances and gave an increased importance to the question how surpluses were to be spent. ${ }^{7}$ Progressive politicians had promised to use surpluses to increase public consumption and, more importantly, public investment. However, they failed to deliver on this promise. Instead, surpluses were mainly used for cutting taxes (Haffert and Mehrtens, 2015). In surplus regimes, the average tax wedge for singles with an average household income was reduced by almost four percentage points between 2000 and 2009 (OECD, 2014). Correspondingly, cyclically adjusted revenue fell by $1.9 \%$ of GDP. In contrast, countries with surplus episodes kept income tax rates almost constant over the entire decade. These countries had enacted extensive tax reductions during the first years of surplus. After returning to deficits, however, they could no longer afford further cuts.

Why did surplus regimes decide to use surpluses for cutting taxes? Finance ministries often described this as an economic strategy for raising competitiveness, in particular through reductions of corporate taxes and income taxes. Cuts of the former were seen as attracting investors from abroad, but also as inducing increasingly footloose national companies to stay. Similarly, income tax cuts aimed to prevent a 'brain drain' of highly educated individuals. Consequently, official documents frequently highlighted the need for income tax rates that could compete with neighboring countries (Department of Finance Canada, 2004, p. 208). Again, governments of different political stripes supported this competitiveness argument. In Canada, the framing of income tax cuts in the first Conservative budget of 2006 was almost identical to the framing in the last Liberal budget of 2005 (Jackson and Weir, 2008, p. 62).

Moreover, tax cuts had clear political benefits. They contributed to generating persistent support for continuing surpluses. Surpluses and tax cuts, while being arithmetic rivalsmoney that is used to balance the budget cannot be returned to taxpayers-were thus political complements. Thanks to persistent surpluses, politicians could credibly commit to future tax cuts because they guaranteed that such cuts could indeed be financed. At the same time, this promise to invest any surpluses in tax cuts ensured the support of the now politically dominant tax-cut coalition. Had this coalition demanded bigger tax cuts in the present, this could have easily derailed the surplus policy. The promise of even bigger cuts in the future thus bought off its support for continued surpluses.

The crucial question, of course, was the credibility of this promise. How could politicians credibly commit to using future surpluses for tax cuts? This commitment-and the related commitment not to increase expenditure-was made possible by the reconfiguration of political interests that had accompanied the consolidation. Faced with the shrinking clout of spending coalitions, even parties of the left increasingly advocated for tax cuts, disagreeing only about their size and composition. Moreover, the new budgetary rules in surplus regimes acquired a surprising importance in this context. Sweden's expenditure ceiling, which prohibited the use of unexpected revenue for anything other than tax cuts or paying down the debt, generated additional credibility for the promise of future tax cuts (Ljungman, 2008). Canada even legislated a 'tax-back guarantee act' in 2007, which stipulated that all interest savings caused by debt reductions had to be used for cutting taxes (Statutes of Canada, 2007).

7 In addition, a resource boom contributed to growing tax revenues in Canada, Australia, New Zealand and, to a lesser extent, Denmark. 
To twist Margaret Levi's famous argument (Levi, 1988), these commitments can be seen as a 'reverse fiscal contract'. Levi argued that generating revenue was easier for governments who could credibly promise to use revenues for financing public goods. The promise of future returns in the form of higher spending would make citizens comply with taxes in the present. In a similar but reversed fashion, the promise of future returns in the form of lower taxes generated support for lower spending (i.e. continuing surpluses) in the present in surplus regimes. In contrast, countries with surplus episodes could not make an analogous promise because the balance of power between tax-cut and expenditure coalitions had not changed during the consolidation.

\section{Conclusion}

What Levi's concept of a fiscal contract points to is the deep political connection between fiscal decisions in the present and the future. This interconnectedness between taxing, spending and budget balances is what justifies speaking of a 'surplus regime' in countries which preserved surpluses. Both how surpluses were spent as well as how they were created had an important impact on their preservation. Only countries that could credibly commit surpluses to future tax cuts were able to preserve them. And only countries that generated surpluses through crisis-induced expenditure cuts were able to make such a commitment.

In these surplus regimes, a fiscal crisis and the subsequent expenditure-led consolidation had strengthened the tax-cut coalition. It was therefore able to shift the burden of fiscal adjustment permanently onto the expenditure coalition, which had been weakened by the same sequence of crisis and consolidation. 'Political interests, institutions, and policy arrangements' (Pierson, 2001) thus became structured around the double goal of balancing the budget and cutting taxes. Countries with surplus episodes, by contrast, remained stuck in a deficit regime. In these countries, there was no similar crisis and only much less fundamental consolidation. The underlying societal conflict between both coalitions was temporarily alleviated by surprisingly strong revenue growth, but never really solved. As soon as the economic boom ended, the conflict arose again and deficits returned.

This regime-based approach thus explains why the literature-without offering a political explanation for this result-has found expenditure-driven consolidations to be more sustainable. Moreover, my approach has implications for the study of fiscal policy more broadly. It calls for attention to the specific historical circumstances in which fiscal policies are made and questions the validity of sweeping generalizations, including the prediction of a permanent 'deficit bias'. In particular, the regime approach shows the limits of a voluntaristic conception of fiscal policy in which policymakers are essentially free to pursue their individual goals and in which their room for maneuver has to be restricted by formal institutional barriers. As I have argued, both the creation and the efficacy of such barriers crucially depend on the underlying fiscal interests that support them.

Furthermore, while institutional reforms are endogenous to the underlying balance of power between fiscal coalitions, this balance of power is itself shaped by prior fiscal policy choices in a path-dependent fashion. As the analysis has demonstrated, the specific composition of consolidation programs set in motion a realignment of interest structures. Thus, fiscal policy is both an outcome and a source of the relative strength of different coalitions. Accordingly, the analysis of fiscal policy should not just consider how struggles between coalitions shape fiscal policy, but also how fiscal decisions feedback on the goals and power of these coalitions. 
This is of particular importance at those junctures where established fiscal regimes get into trouble and the topography of fiscal interests begins to shift. The most recent example of such a juncture, of course, is the fiscal response to the great financial crisis and the euro crisis. Many analyses of these crises focus on the immediate questions of fighting deficits, reassuring financial markets and restarting economic growth. The theoretical framework adopted in this article, however, suggests that the long-term consequences of different policy options are as important as their immediate effects. The decisions taken in response to the crisis are likely to define the path for fiscal policy for many years to come. Indeed, an analysis of Sweden's and Canada's fiscal policies after 2008-which is beyond the scope of this article-would reveal how strongly they were shaped by the consolidation of the 1990s. The Swedish government was very reluctant to pursue an expansionary reaction to the crisis and was even criticized by its own fiscal watchdog (Haffert and Mehrtens, 2015, p. 138). In Canada, the government was more proactive but used the crisis to further its tax-cut agenda (Brenton, 2016, p. 156)

What the specific feedback effects of different policy will be, however, is difficult to foretell at the moment of decision-making. Future research should therefore analyze the reconfiguration of fiscal coalitions on a much more systematic scale, in order not just to identify them ex post but also to anticipate them ex ante.

\section{Acknowledgements}

I would like to thank Pepper Culpepper, Vytautas Kuokstis, Arjan Reurink, seminar participants at the ECPR joint sessions Warsaw 2015 and three anonymous reviewers for many helpful comments.

\section{References}

Alesina, A. (2000) 'The Political Economy of the Budget Surplus in the United States', Journal of Economic Perspectives, 14, 3-19.

Alesina, A. and Ardagna, S. (2012) The Design of Fiscal Adjustments, NBER Working Paper 18423, Cambridge, MA, National Bureau of Economic Research.

Alesina, A. and Drazen, A. (1991) 'Why are Stabilizations Delayed?', American Economic Review, 81, 1170-1188.

Alesina, A. and Passalacqua, A. (2015) The Political Economy of Government Debt, NBER Working Paper 21821, Cambridge, MA, National Bureau of Economic Research.

Alesina, A. and Perotti, R. (1995) Fiscal Expansions and Fiscal Adjustments in OECD Countries, NBER Working Paper 5214, Cambridge, MA, National Bureau of Economic Research.

Alesina, A. and Tabellini, G. (1990) 'A Positive Theory of Fiscal Deficits and Government Debt', Review of Economic Studies, 57, 403-414.

Arter, D. (2012) 'Big Bang' Elections and Party System Change in Scandinavia: Farewell to the 'Enduring Party System'?', Parliamentary Affairs, 65, 822-844.

Baldacci, E., Petrova, I., Belhocine, N., Dobrescu, G. and Mazraani, S. (2011) Assessing Fiscal Stress, IMF Working Paper 11/100, Washington, DC, International Monetary Fund.

Barta, Z. (2011) Flirting with Disaster-Explaining Excessive Public Debt Accumulation in Italy and Belgium, PhD Dissertation, London, London School of Economics and Political Science.

Blomqvist, P. (2004) 'The Choice Revolution: Privatization of Swedish Welfare Services in the 1990s', Social Policy \& Administration, 38, 139-155.

Blöndal, J. (2001) 'Budgeting in Canada', OECD Journal on Budgeting, 1, 39-82. 
Blyth, M. (2013) Austerity. The History of a Dangerous Idea, Oxford, Oxford University Press.

Bourgon, J. (2009) The Government of Canada's Experience Eliminating the Deficit, 1994-1999, Waterloo, Centre of International Governance Innovation.

Brenton, S. (2016) The Politics of Budgetary Surplus. Ideology, Economic Governance and Public Management Reform, London, Palgrave Macmillan.

Brenton, S. and Pierre, J. (2017) 'Budget surplus goal experiments in Australia and Sweden', New Political Economy, 22, 557-572.

Buchanan, J. M. (1967) 'Fiscal Policy and Fiscal Preference', Public Choice, 2, 1-10.

Buchanan, J. M. and Wagner, R. E. (1977) Democracy in Deficit: The Political Legacy of Lord Keynes, New York, Academic Press.

Budina, N., Kinda, T., Schaechter, A. and Weber, A. (2012) Fiscal Rules at a Glance: Country Details from a New Dataset, IMF Working Paper 12/273, Washington, DC, International Monetary Fund.

Busemeyer, M. and Iversen, T. (2014) 'The Politics of Opting Out: Explaining Educational Financing and Popular Support for Public Spending', Socio-Economic Review, 12, 299-328.

Buti, M. and Pench, L. (2004) 'Why Do Large Countries Flout the Stability Pact. And What Can be Done About It?', Journal of Common Market Studies, 42, 1025-1032.

Calmfors, L. (2012) Sweden - from Macroeconomic Failure to Macroeconomic Success, CESifo Working Paper 3790, Munich, Center for Economic Studies ifo Institut.

Calmfors, L. and Wren-Lewis, S. (2011) What Should Fiscal Councils Do?, CESifo Working Paper No. 3382, Munich, Center for Economic Studies ifo Institut.

Campbell, A. L. (2012) 'Policy Makes Mass Politics', Annual Review of Political Science, 15, 333-351.

Capoccia, G. and Kelemen, D. (2007) 'The Study of Critical Junctures. Theory, Narrative, and Counterfactuals in Historical Institutionalism', World Politics, 59, 341-369.

Courchene, T. J. (2002) 'Half-Way Home: Canada's Remarkable Fiscal Turnaround and the Paul Martin Legacy', Policy Matters, 03/08, Montreal, Institute for Research on Public Policy.

Cox, G. and McCubbins, M. (2001) 'The Institutional Determinants of Economic Policy Outcomes'. In Haggard, S. and McCubbins, M. (eds) Presidents, Parliaments, and Policy, Cambridge, Cambridge University Press, pp. 21-63.

Department of Finance Canada (1999) Budget Plan, Ottawa.

Department of Finance Canada (2001) Budget Plan, Ottawa.

Department of Finance Canada (2004) Budget Plan, Ottawa.

DeVries, P., Guajardo, J., Leigh, D. and Pescatori, A. (2011) A New Action-based Dataset of Fiscal Consolidation, IMF Working Paper 11/128, Washington, DC, International Monetary Fund.

Edlund, J. (2006) 'Trust in the Capability of the Welfare State and General Welfare State Support: Sweden 1997-2002', Acta Sociologica, 49, 395-417.

Emigh, R. (1997) 'The Power of Negative Thinking: The Use of Negative Case Methodology in the Development of Sociological Theory', Theory and Society, 26, 649-684.

Esping-Andersen, G. (1990) The Three Worlds of Welfare Capitalism, Cambridge, Polity Press.

Fladmoe, A. (2012) 'Mass Political Polarization and Attitudes Towards Education as Part of the Welfare State in Norway, Sweden and Finland', Journal of European Social Policy, 22, 45-62.

Fortin, P. (1996) 'The Great Canadian Slump', Canadian Journal of Economics, 29, 761-787.

Franzese, R. J. (2002) 'Electoral and Partisan Cycles in Economic Policies and Outcomes', Annual Review of Political Science, 5, 369-421.

Gaard, S. and Kieler, M. (2005) Two Decades of Structural Reform in Denmark: a Review, Working Paper 16/2005, Copenhagen, Finansministeriet.

Giavazzi, F. and Pagano, M. (1990) 'Can Severe Fiscal Contractions Be Expansionary? Tales of Two Small European Countries', NBER Macroeconomics Annual, 5, 75-122.

Gingrich, J. (2011) Making Markets in the Welfare State: The Politics of Varying Market Reforms, Cambridge, Cambridge University Press. 
Goodale, R. (2004) New Agenda for Achievement, Budget Speech 2004, Department of Finance Canada.

Haffert, L. and Mehrtens, P. (2015) 'From Austerity to Expansion? Consolidation, Budget Surpluses, and the Decline of Fiscal Capacity', Politics \& Society, 43, 119-148.

Hallerberg, M. (2004) Domestic Budgets in a United Europe, Ithaca, Cornell University Press.

Hallerberg, M., Strauch, R. and Von Hagen, J. (2009) Fiscal Governance in Europe, Cambridge, Cambridge University Press.

Henriksson, J. (2007) Ten Lessons about Budget Consolidation, Brussels, Bruegel.

Huber, E. and Stephens, J. D. (2000) 'Partisan Governance, Women's Employment, and the Social Democratic Service State', American Sociological Review, 65, 323-342.

Hübscher, E. (2016) 'The Politics of Fiscal Consolidation Revisited', Journal of Public Policy, 36, 573-601.

Hübscher, E. and Sattler, T. (2017) 'Fiscal Consolidation under Electoral Risk', European Journal of Political Research, 56, 151-168.

ILO (2013) LABORSTA Labour Statistics Database, International Labour Organization, Geneva.

IMF (2002a) Sweden: Selected Issues, IMF Country Report 02/160, Washington, D.C.

IMF (2002b) Canada: Article IV Consultation-Staff Report and Public Information Notice on the Executive Board Discussion, Washington, D.C.

Iversen, T. and Soskice, D. (2006) 'Electoral Institutions and the Politics of Coalitions: Why Some Democracies Redistribute More Than Others', American Political Science Review, 100, 165-181.

Jackson, A. and Weir, E. (2008) 'The Conservative Tax Record. More of the Same, or a Turn for the Worse?'. In Healy, T. (ed.) The Harper Record, Ottawa, Canadian Centre for Policy Alternatives, pp. 57-69.

Kelly, J. (2002) 'Budgeting and Program Review in Canada 1994-2000', Australian Journal of Public Administration, 59, 72-78.

Kenney, J. (2001) Budget Debate, Parliament of Canada, Edited Hansard. 37th Parliament, 1st Session, 11.12.2001.

Levi, M. (1988) Of Rule and Revenue, Berkeley, Unviersity of California Press.

Lewis, T. (1999) The Political Economy of Debt and Deficit Politics in Canada, University of Toronto.

Lewis, T. (2003) In the Long Run We're All Dead: The Canadian Turn to Fiscal Restraint, Vancouver, UBC Press.

Lindbeck, A. (1997) 'The Swedish Experiment', Journal of Economic Literature, 35, 1273-1319.

Lindh, Y. and Ljungman, G. (2007) 'Fiscal Rules and the Scope for Stabilisation Policy - The Case of Sweden'. In d'Italia Banca (ed.) Fiscal Policy: Current Issues and Challenges, Rome, pp. 29-53.

Ljungman, G. (2008) Expenditure Ceilings-A Survey, IMF Working Paper 08/282, Washington, DC, International Monetary Fund.

MacKinnon, J. (2003) Minding the Public Purse. The Fiscal Crisis, Political Trade-offs and Canada's Future, Montreal, McGill-Queen's University Press.

Maclean's (2002, December 30) 'The Year-End Poll', Toronto, Maclean, pp. 24.

Martin, P. (2001) Securing Progress in an Uncertain World, Budget Speech 2001, Department of Finance Canada.

Mehrtens, P. (2014) Staatsschulden und Staatstätigkeit: Zur Transformation der politischen Ökonomie Schwedens., Frankfurt, Campus.

Mulas-Granados, C. (2006) Economics, Politics and Budgets. The Political Economy of Fiscal Consolidations in Europe, Basingstoke, Palgrave Macmillan.

Nannestad, P. and Green-Pedersen, C. (2008) 'Keeping the Bumblebee Flying. Economic Policy in the Welfare State of Denmark, 1973-1999'. In Albaek, E, Eliason, L., Norgaard, A. and Schwartz, H. (eds) Crisis, Miracles, and Beyond, Aarhus, Aarhus University Press, pp. 33-74. 
Nuder, P. (2012) ‘Sweden’s Social Democratic Consolidation'. In Springford, J. (ed.) Dealing With Debt: Lessons from Abroad, London, CentreForum, pp. 55-73.

O’Neill, T. (2005) Review of Canadian Federal Fiscal Forecasting. Processes and Systems, Toronto, O'Neill Strategic Economics.

OECD (2014) Taxing Wages, Paris.

Palmer, R. and Egan, L., (2011, November 22) 'Chrétien says austerity measures work; Cuts to social programs in 1990s saved Canada from turning into what Greece is today', Toronto, The Globe and Mail, pp. B8.

Patashnik, E. M. (2008) Reforms at Risk. What Happens After Major Policy Changes are Enacted, Princeton, Princeton University Press.

Persson, G. (1996) 'The Swedish Experience in Reducing Budget Deficits and Debt', Economic Review, 81, 7-9.

Pierson, P. (2001) 'From Expansion to Austerity. The New Politics of Taxing and Spending'. In Levin, M. A., Landy, M. K. and Shapiro, M. (eds) Seeking the Center: Politics and Policymaking in the New Century, Washington, D.C., Georgetown University Press, pp. 54-80.

Posner, P. and Gordon, B. (2001) 'Can Democratic Governments Save? Experiences of Countries with Budget Surpluses', Public Budgeting \& Finance, 21, 1-28.

Sancak, C., Liu, L. and Nakata, T. (2011) 'Canada: A Success Story’. In Mauro, P. (ed.) Chipping Away at Public Debt, Hoboken, Wiley, pp. 1-29.

Schwartz, H. (1994) 'Small States in Big Trouble: State Reorganization in Australia, Denmark, New Zealand, and Sweden in the 1980s', World Politics, 46, 527-555.

Soifer, H. D. (2012) 'The Causal Logic of Critical Junctures', Comparative Political Studies, 45, 1572-1597.

Standard \& Poor's. (2011) Sovereign Rating and Country T\&C Assessment Histories. 3.8.2011, New York, Standard \& Poor's.

Statutes of Canada (2007) Tax-back Guarantee Act, Ottawa.

Steinmo, S. (2002) 'Globalization and Taxation: Challenges to the Swedish Welfare State', Comparative Political Studies, 35, 839-862.

Streeck, W. (2017) 'A New Regime: The Consolidation State'. In King, D. and Le Galès, P. (eds) Reconfiguring European States in Crisis, Oxford, Oxford University Press, pp. 139-157.

Svallfors, S. (2011) 'A Bedrock of Support? Trends in Welfare State Attitudes in Sweden, 1981-2010', Social Policy \& Administration, 45, 806-825.

Svallfors, S. (2016) 'Politics as Organized Combat. New Players and New Rules of the Game in Sweden', New Political Economy, 21, 505-519.

Timonen, V. (2003) Restructuring the Welfare State. Globalization and Social Policy Reform in Finland and Sweden, Cheltenham, Edward Elgar.

Vartiainen, J. (2011) 'The Finnish Model of Economic and Social Policy - from Cold War Primitive Accumulation to Generational Conflicts?'. In Mjoset, L. (ed.) The Nordic Varieties of Capitalism, Bingley, Emerald, pp. 53-87.

Von Hagen, J., Hallett, A. and Strauch, R. (2002) 'Budgetary Consolidation in Europe: Quality, Economic Conditions, and Persistence', Journal of the Japanese and International Economies, 16, 512-535.

Wagschal, U. and Wenzelburger, G. (2008) 'Roads to Success: Budget Consolidations in OECD Countries', Journal of Public Policy, 28, 309-339.

Weaver, R. K. (ed.) (1992) The Collapse of Canada?, Washington, D.C., Brookings Institution.

Wenzelburger, G. (2010) Haushaltskonsolidierungen und Reformprozesse, Berlin, LIT.

Wenzelburger, G. (2013) 'Fact or Fiction? Welfare Cuts and Fiscal Adjustments', Journal of Public Policy, 34, 63-92.

Wildavsky, A. (1975) Budgeting: A Comparative Theory of Budgetary Processes, Boston, Little, Brown. 